посіб.] / В. І. Бондар. - Київ : Либідь, 2005. - 264 с. 3. Дидактика географії: [монографія] / В. М. Самойленко, О.М. Топузов, Л. П. Вішнікіна, О. Ф. Надтока, І. О. Діброва. - Київ : Педагогічна думка, 2014. - 586 с. 4. Гершунский Б. С. Концепция самореализации личности в системе обоснования ценностей и целей образования / Б. С. Гершунский // Педагогика. 2003. - № 10. - С. 3-7. 5. Концепція географічної освіти в основній школі: проект/ Інститут педагогіки НАПН України / за заг. ред. О. М. Топузов, О. Ф. Надтока, Л. П. Вішнікіна, А. С. Доброскок та ін. - Київ : Педагогічна думка, 2014. - 30 с. 6. Кремень В. Г. Філософія національної ідеї: Людина. Освіта. Соціум / В. Г. Кремень. - Київ : Грамота, 2010. - 576 с. 7. Надтока О. Ф. Особистісно зорієнтований підручник з географії як одна з вимог сучасної освіти / О. Ф. Надтока // Географія та економіка в сучасній школі. - Київ : Педагогічна преса, 2012. - № 1. - С. 6-11. 8. Топузов О. М. Педагогічна прогностика: теоретико-методична основа прогнозування розвитку педагогічних наук і педагогічної практики / О. М. Топузов // Рідна школа. - 2014. - № 7. - С. 32-36.

Інеса Хмеляр

\title{
ДОСЛІДНИЦЬКИЙ ПІДХІД ДО ОРГАНІЗАЦІї НАВЧАЛЬНО-ВИХОВНОГО ПРОЦЕСУ В КОЛЕДЖІ - УМОВА САМОРОЗВИТКУ СТУДЕНТА
}

Хмеляр І. М. Дослідницький підхід до організації навчально-виховного процесу в коледжі - умова саморозвитку студента.

У статті розкрито та науково обгрунтовано застосування в навчально-виховному процесі медичних коледжів дослідницького підходу як однієї з умов саморозвитку студента. Установлено, що дослідницький підхід до навчальної діяльності студента сприяє вихованню особистості, здатної до самореалізації, професійного зростання в умовах реформування сучасного суспільства.

Ключеві слова: саморозвиток, дослідницький підхід, інноваційний процес, самореалізація.

Хмеляр И. М. Исследовательский подход к организации учебно-воспитательного процесса в колледже - условие саморазвития студента.

В статье раскрыто и научно обосновано применение в учебно-воспитательном процессе медицинских колледжей исследовательского подхода как одного из условий саморазвития студента. Установлено, что исследовательский подход к учебной деятельности студента способствует воспитанию личности, способной к самореализации, профессионального роста в условиях реформирования современного общества.

Ключевые слова: саморазвитие, исследовательский подход, инновационный процесс, самореализация.

Hmelyar I. M. Research approach to the organization of educational process in college as a condition for student's self-development.

The adaptation of research approach as one of the conditions for student's self-development in the educational process of medical colleges is revealed and proved. It is determined that the research approach in learning activity contributes to character education for self-actualization and professional growth in the conditions of reforming of modern society.

Key words: self-development, research approach, innovative process, self-actualization.

Педагогіка вищої та середної школи. - 2015. - Вип. 45 
Наш час вимагає від кожного активності, уміння актуалізувати здібності та реалізувати себе як особистість. Ураховуючи закономірність, що саморозвиток особистості залежить від ступеня індивідуалізації i творчої спрямованості навчально-виховного процесу - передбачає пошук технологій навчання, які б зосередили увагу на особистості студента, створення умов для його творчого розвитку, самовираження. Як результат - поява інноваційних технологій у педагогіці [5; 7; 11; 12].

Сутність закономірності полягає в тому, що будь-який інноваційний процес вносить незворотні деструктивні зміни в педагогічне середовище, створюючи проблеми. Кожне нововведення завжди має критиків. Чим грунтовніше нововведення, тим імовірнішою буде дестабілізація, яка стосується теоретичного, дослідницького, комунікативного і практичного середовища. Фінальна реалізація інноваційного процесу полягає в обов'язковій реалізації планів. Ускладнення соціальних i виробничих зв'язків, науково-технічні чинники, розширення обсягу інновацій визначають нові вимоги до загальнокультурної та професійної підготовки педагогів. Особливого значення набуває становлення особистості педагога, його гуманістичної сутності. У сучасних умовах суспільству потрібен не виконавець адміністративних вказівок, а висококомпетентний, розвинений професіонал - педагог, який володіє глибокими педагогічними знаннями, надбаннями національної та світової культури, здатний до творчості, нестандартних рішень, готовий до роботи в умовах ринкових відносин $[7 ; 9 ; 12]$.

Розвиток творчого потенціалу є однією з основних умов прогресу суспільства [11]. Це визначає причини, які спонукали звернути увагу на формування у студентів різноманітної, глибокої і міцної системи знань, на максимальну стимуляцію їх самостійної оперативності й дієвості, на розвиток стійких творчих інтересів, цілеспрямованості творчих пошуків, наполегливості під час виконання творчих завдань $[4 ; 5 ; 8 ; 12]$.

Аналіз літературних джерел [5; 6; 8; 9] надає змогу стверджувати, що проблема організації навчально-виховного процесу 3 природничих дисциплін $\epsilon$ недостатньо розробленою та потребує подальших спеціальних досліджень. Зокрема, на сучасному етапі розвитку науки актуальними та проблемними залишаються такі питання: оновлення методів, засобів і форм організації навчання; шляхи упровадження інноваційних технологій; використання нетрадиційних методів i форм навчання; міжпредметна інтеграція i формування цілісних знань; формування адекватної самооцінки; прагнення до самоосвіти.

Традиційна система освіти в більшості випадків є освітою інформаційного типу, що сприяє формуванню знань, умінь і навичок, а не особистісному розвитку, хоча не заперечує його. Авторитарна педагогіка, побудована на примусі, породжує тривогу, страх, які призводять до блокування активності, самостійності, що в кінцевому результаті гальмує саморозвиток особистості $[1 ; 4]$. Здійснений нами аналіз літератури з цього питання дозволяє зазначити, що зміст сучасної освіти повинен містити такі компоненти: аксіологічнийнадання допомоги у виборі системи ціннісних орієнтацій; освітній- забезпечення науковими знаннями; діяльнісно-творчий- формування i розвиток творчих здібностей, різних способів діяльності; особистісний- оволодіння способами саморегуляції, самовдосконалення, навичками самоосвіти.

Ураховуючи співвідношення науки і навчальних предметів, наукових принципів побудови навчальних планів, програм i підручників установлено, що програмовий навчальний матеріал повинен передбачати: а) повідомлення певної суми знань, інформації, яку повинен отримати студент; б) подання інформації таким чином, щоб правильно 
розвивати інтелект.

Н. Буринська [4] змісту навчального матеріалу надає великого значення, зокрема зазначає, що вдало дібрані цікаві факти, історичні курйози, жарти, відомості з художньої літератури сприяють формуванню в учнів вільного творчого володіння навчальним матеріалом. Дослідниця звертає увагу на те, що зміст навчального матеріалу з предмета не завжди $є$ цікавим. Тому вдало організований навчальний процес, відповідно дібрані форми і методи навчання сприятимуть підвищенню інтересу до вивчення предмета. Це передбачає використання в навчально-виховному процесі проблемного та діяльнісного підходів, мультимедійних технологій, комп'ютерних програм.

Вище висвітлене дозволяє зробити висновок, що технологіям, які сприяють саморозвитку особистості, відповідають такі ознаки: демократичність; гнучкість; використання непрямих способів управління в поєднанні з самоуправлінням; навчальна діяльність спрямована на розпізнавання навчально-творчих завдань [7; 12].

Дослідницький підхід до навчання вимагає створення методів, розрахованих передусім не на трансляцію знань, а на їх засвоєння, тому що знання передати неможливо, якщо не буде навчальної діяльності студента із їх засвоєння. У роботах багатьох науковців звертається увага на питання цілеспрямованого підхіду до педагогічного процесу, до навчально-виховної діяльності, у процесі якої повинна розвиватися і формуватися особистість студента, яка прагне вчитися.

На основі аналізу наукових джерел з'ясовано, що проблема саморозвитку студентів розглядається в таких основних напрямах: визначення рівня саморозвитку студента; розкриття особливостей та характеристика механізму формування саморозвитку студентів у BH3.

Опрацьовуючи дослідження науковців 3 проблеми дослідницького підходу до організації навчально-виховного процесу, виокремлюємо такі етапи: 1) постановка мети чітке усвідомлення конкретного завдання; 2) планування роботи - вибір найраціональнішого способу дії; 3) виконання - здійснення дослідження проблеми; 4) перевірка результатів; 5) виправлення помилок (якщо є); 6) зіставлення одержаних результатів із запланованими; 7) підведення підсумків роботи.

У процесі дослідження відбувається формування та розвиток пам'яті, уваги, мислення, що є основною умовою саморозвитку особистості.

Процес саморозвитку особистості студента безпосередньо залежить від рівня організації навчальної діяльності. Навчальною діяльністю називаємо систему ознак саморозвитку особистості, від яких залежить продуктивність процесу навчання особистості. До ознак показників саморозвитку особистості відносимо: глибину- це ознака, яка відображає вміння студента абстрагувати під час оволодіння новим матеріалом, розв'язання проблемних ситуацій, уміння узагальнювати та робити висновки, уміння проникати у сутність найскладніших питань життя; гнучкість - уміння переходити від прямих зв'язків до зворотніх, від однієї системи дій до іншої; легкість, свобода думки під час вибору способу розв'язання завдань, швидко переключатися з одного способу розв'язування на інший; стійкість - виявляється в орієнтації на раніше засвоєні закони, поняття, терміни, незважаючи на дію різних провокуючих випадкових ознак; широту- характеризується всебічним та творчим підходом до різних питань науки i практики, врахування міжпредметних зв'язків; самостійність - виражається в умінні визначення проблеми, мети, висуванні гіпотези і самостійному розв'язанні поставлених завдань; усвідомленість - вміння виявити допущені помилки, проаналізувати причини їх виникнення, вказати ознаки, на які 
орієнтувався під час виконання завдання; критичність - уміння об'єктивно оцінювати свої та чужі думки, ретельно доводити і всебічно перевіряти всі висунуті положення та висновки; швидкість - здатність людини швидко зорієнтуватися у складній ситуації, обдумати та негайно прийняти правильне рішення.

Узагальнивши підходи до формування творчих здібностей, визначаємо такі ознаки їх вияву: швидкість думки, точність, рівень мотивації, рівень розвиненої уяви. Названі ознаки формуються і розвиваються в діяльності студента на основі різних педагогічних підходів, які спрямовані на особистість. Для того щоб створити відповідні умови, які забезпечили б саморозвиток, потрібно пізнати структуру особистості, що можливе при впровадженні дослідницького підходу. За твердженням С. Сисоєвої [12], сутність такого навчання полягає в тому, що навчально-виховний процес базується на визнанні принципу педагогічної взаємодії, стимулюванні індивідуальної і колективної творчості, що передбачає використання в навчально-виховному процесі технології навчання, які «забезпечують взаємодію трьох взаємозумовлених чинників впливу на розвиток особистості: мотиваційного, особистісного і діяльнісного» [12, с. 153]. Під час організації навчальновиховного процесу ураховуємо: використання форм і методів індивідуалізації й диференціації навчання, досвід студента, створення сприятливих умов для самоосвіти, саморозвитку, комплексне використання інформаційних технологій навчання, елементів проблемного навчання, нетрадиційних підходів до організації навчально-виховного процесу, організацію об'єктивного контролю знань, умінь та навичок. Розв'язання задач є одним із засобів оволодіння системою знань із того чи того навчального предмета і водночас сприяє розвитку самостійного творчого мислення. Ознайомлюючись із навчальним матеріалом, студенти за допомогою викладача виконують такі дії: аналізують зміст навчального матеріалу, будують змістову абстракцію вивченого матеріалу, встановлюють зв'язок між новим матеріалом i раніше засвоєним, узагальнюють послідовність набутих знань, створюють цілісну систему нових знань, самоконтроль, самооцінку, корекцію діяльності. У курсі хімії, як і в курсах предметів природничо-математичного циклу, передбачено задачі. За своїм характером задачі можуть бути різними: 1) типові розрахункові задачі, що завжди $є$ на початковій стадії навчання; 2) експериментальні задачі, де студенти демонструють свої знання, вміння та навички під час проведення дослідів; 3) аналітичні - задачі, які вимагають переосмислення відомих алгоритмів розв'язку відповідно до аналізу конкретних умов; 4) творчі - це пошукові задачі, що вимагають віднайдення нових способів розв'язку, уміння вести пошук у різних напрямках.

Після того, як відбулося усвідомлення розв'язання творчої задачі, про що свідчить подання іiі у вигляді схеми, готової до використання, задача для студента стає типовою. Великого значення ми надаємо завданням, які сприяють удосконаленню знань і виробленю вмінь використовувати їх. Такими завданнями вважаємо вправи, що складаються 3 аналогічних завдань, та диференційовані індивідуальні завдання із зростаючою трудністю.

Використання дослідницького підходу в навчальній діяльності передбачає організацію роботи зі студентами за такими трьома напрямами:

1. Правильно визначати цільову настанову: відзначати, перераховувати факти, все, що підлягає засвоєнню; давати загальне уявлення про тему, яку потрібно вивчити; звертати увагу на новизну виучуваного матеріалу, приділяти увагу критиці, критичному ставленню до підручника, робити прогнозування.

2. Активізувати контроль за сприйняттям (незрозуміле, суперечливе, неправильне).

3. Підвищувати темп уявних операцій, звертати увагу на глибину і чіткість їх 
усвідомлення.

Такий підхід до організації навчально-виховного процесу в коледжі має низку переваг: а) пропонується схема (алгоритм), де висвітлені завдання (рівень завдань студент вибирає сам), представлена система необхідної дії; б) завдання побудовані так: указана мета, зазначено способи виконання: стратегія задана завданням, а тематику обирає студент.

Аналіз успішності студентів надає змогу дійти висновку, що дослідницький підхід до навчання сприяє не тільки більш глибокому і міцному засвоєнню навчального матеріалу, але і способів діяльності.

Таблиия 1

Динаміка рівнів сформованості начальних досягнень

під час експерименту

\begin{tabular}{|c|c|c|c|c|c|c|}
\hline \multirow[b]{2}{*}{ Відділення } & \multirow{2}{*}{$\begin{array}{c}\text { Етапи } \\
\text { експерименту }\end{array}$} & \multirow{2}{*}{$\begin{array}{c}\text { Кількість } \\
\text { студентів, } \\
\text { ос. }\end{array}$} & \multicolumn{4}{|c|}{ Рівні сформованості творчих здібностей } \\
\hline & & & Недостатній & Низький & Достатній & и Високий \\
\hline \multirow{2}{*}{$\begin{array}{c}\text { Лікувальна } \\
\text { справа }\end{array}$} & Початок & \multirow{2}{*}{120} & $3,20 \%$ & $72,60 \%$ & $21,00 \%$ & $3,20 \%$ \\
\hline & Закінч. & & & $61,72 \%$ & $32,03 \%$ & $6,25 \%$ \\
\hline \multirow{2}{*}{$\begin{array}{c}\text { Сестринська } \\
\text { справа }\end{array}$} & Початок & \multirow{2}{*}{90} & $3,05 \%$ & $70,99 \%$ & $22,14 \%$ & $3,82 \%$ \\
\hline & Заверш. & & & $44,27 \%$ & $41,22 \%$ & $14,51 \%$ \\
\hline \multirow{2}{*}{ Фармація } & Початок & \multirow{2}{*}{90} & $1,56 \%$ & $74,78 \%$ & $19,08 \%$ & $4,58 \%$ \\
\hline & Заверш. & & & $31,30 \%$ & $48,85 \%$ & $19,85 \%$ \\
\hline
\end{tabular}

Важливими результатами використання такого підходу, ми вважаємо, є: розвиток пізнавальних процесів, засвоєння нових знань понять, актуалізація мислення задля віднайдення й побудови навчальних дій розв'язання проблеми, підвищення мотивації.

Дослідницький підхід до організації навчально-виховного процесу в коледжі сприяє: 1) забезпеченню адаптації випускника до сучасних умов життя; 2) реалізації системного та індивідуального підходів до створення структури саморозвитку студента; 3) виробленню навичок самостійної науково-практичної, дослідницько-пошукової діяльності; 4) забезпеченню сприятливих умов розвитку навчально-пізнавальних i професійних інтересів, здібностей і потреб майбутніх медичних працівників та суспільних вимог; 5) виховуванню особистісті, здатної до самореалізації, професійного зростання в умовах реформування сучасного суспільства.

\section{Література}

1. Аванесов В. С. Вопросы объективизации результатов обучения / В. С. Аванесов. Москва : Наука, 1993. - 220 с. 2. Андреев И. А. Диалектика воспитания и самовоспитания творческой личности / И. А. Андреев. - Казань : Из-во Казанского университета, 1988. - 345 с. 3. Богоявленская Д. Б. Психология творческих способностей: [учебное пособие для студ. высш. учеб. заведений, обуч. по напр. и спец. психологии] / Д. Б. Богоявленская. - Москва : Академия, 2002. - 320 с. 4. Буринська Н. М. Як зробити навчання хімії цікавим / Н. М. Буринська // Біологія і хімія в школі. - 2006. - № 5- С. 6-7. 5. Вишнякова И. Ф. Креативная аксиология. Психология высшего образования: [монография]: в 2 т./ И. Ф. Вишнякова. - Минск : ООО «Дэбор», 1999. - Т. 1 : Психология развития творческой личности взрослого человека. - 1999. - 238 с. б. Выготский Л. С. Педагогическая психология / Л. С. Выготский [ред. В. В. Давыдова]. - Москва : Педагогика, 1991. - 480 с. 7. Свдокімов О. В. Ефективність нових технологій організації навчання студентів / О. В. Свдокімов // Педагогіка і психологія. - 1997. - № 2. - С. 161-170. 8. Леонтьев А. Н. 
Мотивационная основа интереса к учению / А. Н. Леонтьев // Советская педагогика. - 1987. № 7. - С. 130-131. 9. Лернер И. Я. Дидактические основы методов обучения / И. Я. Лернер. - Москва : Педагогика, 1981. - 181 с. $\quad$ 10. Лицур Ю. М. Проблема впровадження нових освітніх технологій з хімії у навчальний процес навчальних закладів різних рівнів акредитації / Ю. М. Лицур, Л. М. Романишина, І. М. Хмеляр // Наукові записки : [зб. наук. ст. Національного педагогічного університету імені М. П. Драгоманова] / укл. П. В. Дмитренко, Л. Л. Макаренко. - Вип. LXII (62). - Київ : НПУ імені М. П. Драгоманова, 2006. - С. 103-108. 11. Професійна освіта: педагогіка і психологія / за ред. Г. Левовицького, I. Вільги, І. Зязюна, Н. Ничкало. - В-во Вищої Педагогічної Школи у Честохові, 2003. 567 с. 12. Сисоєва С. О. Творчий розвиток особистості в процесі неперервної професійної освіти. Неперервна професійна освіта: теорія і практика: [зб. наук. праць] / за ред. І. А. Зязюна та Н. Г. Ничкало. - Київ, 2001. - Ч. 1. - С. 176-212. 13. Хмеляр І. М. Розвиток розумових здібностей учнів (творчості, логічного та абстрактного мислення) на уроках хімії / I. М. Хмеляр // Теорія та методика вивчення природничо-математичних i технічних дисциплін : Наукові записки Рівненського державного гуманітарного університету : [збірник науково-методичних праць]. - Випуск 7. - Рівне : РДГУ, 2004. - С. 65-69.

\section{Елла Часова, Віталій Івчук}

\section{МОЖЛИВОСТІ ВИКОРИСТАННЯ ХМАРНИХ ТЕХНОЛОГІЙ У ВИВЧЕННІ ХІМЇ̈ ІНОЗЕМНИМИ СТУДЕНТАМИ ПІДГОТОВЧОГО ВІДДІЛЕННЯ}

Часова Е. В., Івчук В. В. Можливості використання хмарних технологій у вивченні хімії іноземними студентами підготовчого відділення.

У статті розглядаються особливості використання хмарних технологій у навчанні хімії іноземних студентів підготовчого відділення. Застосування хмарних технологій в освіті може полягати, наприклад, у використанні особистих кабінетів для студентів і викладачів, електронних щоденників та журналів, інтерактивного деканату, де студенти можуть здійснювати обмін інформацією з професорсько-викладацьким складом та ін. Наводиться низка умов, необхідних для забезпечення розвитку і функціонування методичної системи навчання хімії, заснованої на інтеграції організації самостійної роботи студентів із застосуванням хмарних технологій і традиційними засобами навчання.

Ключові слова: хмарні технології, вивчення хімії, іноземні студенти, самостійна робота.

Часова Э. В., Ивчук В. В. Возможности использования облачных технологий в изучении химии иностранными студентами подготовительного отделения.

В статье рассматриваются особенности использования облачных технологий в обучении химии иностранных студентов подготовительного отделения. Применение облачных технологий в образовании может заключаться, например, в использовании личных кабинетов для студентов и преподавателей, электронных дневников и журналов, интерактивного деканата, где студенты могут осуществлять обмен информацией с профессорско-преподавательским составом и др. Приводится ряд русловий, необходимых для обеспечения развития и функционирования методической системы обучения химии, основанной на интеграции организации самостоятельной работы студентов с применением облачных технологий и традиционными средствами обучения. 